\title{
SITUS-SITUS BERSEJARAH DI KECAMATAN SAROLANGUN
}

\author{
(Historical Sites In Sarolangun Sub-District)
}

Nainunis Aulia Izza, Ari Mukti Wardoyo Adi, dan Nugrahadi Mahanani

Program Studi Arkeologi, Universitas Jambi

Jalan Jambi-Muara Bulian Km. 15, Mendalo Indah

Pos-el : nainunis@unja.ac.id (corresponding author), ariwardoyo@unja.ac.id, nmahanani@unja.ac.id

\begin{tabular}{|c|c|}
\hline INFO A & $4 C T$ \\
\hline $\begin{array}{l}\text { stori Artikel } \\
\text { terima : } 30 \text { November } 2021 \\
\text { revisi : } 26 \text { Maret } 2021 \\
\text { setujui : } 8 \text { April } 2021 \\
\end{array}$ & $\begin{array}{l}\text { is study aims to discuss historical sites from pre-colonial to } \\
\text { lonial period in Sarolangun sub-district with Historical } \\
\text { chaeology method and perspective. The result shows that } \\
\text { rolangun subdistrict area is one of center for human activities }\end{array}$ \\
\hline $\begin{array}{l}\text { Keywords: } \\
\text { Classical, Colonial, } \\
\text { Islamic, Sarolangun }\end{array}$ & $\begin{array}{l}\text { since Classical Period until Colonial period, and Nowadays as } \\
\text { the capital of Sarolangun Regency. The data shows, two sites } \\
\text { Classical period in Sarolangun sub-district reused as sacred sites } \\
\text { (langgar and cemetery) during Islamic period. When Sarolangun } \\
\text { under Dutch Colonial period, Sarolangun sub-district is one of } \\
\text { strategic area in Sumatra. The evidence is traceable by the } \\
\text { constructions of various facilities and infrastructure related to } \\
\text { colonial interest. }\end{array}$ \\
\hline
\end{tabular}

\begin{abstract}
ABSTRAK
Penelitian ini bertujuan untuk membahas situs-situs dari masa prakolonial hingga kolonial yang ada di Kecamatan Sarolangun dengan metode dan sudut pandang Arkeologi Kesejarahan. Hasil penelitian menunjukkan wilayah Kecamatan Sarolangun sebagai tempat yang strategis sehingga dipilih sebagai tempat berlangsungnya aktivitas manusia sejak masa Klasik yang terus berlanjut masa Islam dan Kolonial hingga sekarang menjadi ibukota Kabupaten Sarolangun. Berdasarkan penelitian yang telah dilakukan, situs-situs klasik di Kecamatan Sarolangun dimanfaatkan kembali sebagai situs sakral (langgar dan makam) pada masa Islam. Pada masa kolonial Belanda, Kecamatan Sarolangun adalah wilayah yang dianggap strategis. Posisi strategis ini ditandai dengan pembangunan berbagai sarana dan nrasarana untuk kenentinoan colnnial
\end{abstract}




\section{PENDAHULUAN}

Kecamatan Sarolangun merupakan pusat kegiatan perekonomian dan pemerintahan di Kabupaten Sarolangun, Provinsi Jambi. Lokasi pusat-pusat kegiatan tersebut terletak di pertemuan antara Sungai Batang Tembesi dan Sungai Batang Asai yang termasuk dalam wilayah DAS Batanghari (Melisah, 2016). Bukti keberadaan pusat kegiatan ekonomi dapat diketahui dari keberadaan Pasar Atas dan Pasar Bawah yang terletak di tepi Sungai Batang Asai, sedangkan pusat kegiatan pemerintahan saat ini terpusat di kompleks perkantoran Pemerintah Daerah Kabupaten Sarolangun di Gunung Kembang (Makmun, 2018).

Sungai merupakan prasarana transportasi utama yang menghubungkan antara wilayah pedalaman dan pesisir, terutama di Pulau Sumatra bagian selatan sejak periode Prasejarah hingga Sriwijaya (Manguin, 2009). Umumnya, pertemuan sungai merupakan pusat dari aktivitas masyarakat masa lalu yang melakukan perdagangan antara wilayah hulu dan hilir. Oleh karena itu, pusat-pusat kegiatan selalu terdapat di lokasi yang menjadi pertemuan sungai-sungai besar (Bronson, 1977). Kemunculan pusat perekonomian dan pemerintahan di Kecamatan Sarolangun tidak dapat dilepaskan dari adanya pertemuan Sungai Batang Asai dan Sungai 
Selatan. Ketinggian jembatan yang dibangun juga menunjang lalu lintas kapalkapal besar yang melalui sungai tersebut, apalagi semenjak tragedi tenggelamnya kapal Ophelia pada 1931 (Zentgraaf \& Goudoever, 1947). Apabila dibandingkan dengan pembangunan Jembatan Batanghari I di Kota Jambi yang dilakukan pada akhir tahun 1980-an, Jembatan Beatrix telah berdiri 50 tahun lebih awal (Yusuf, 2008).

Keadaan ini membuat kajian tentang lokasi-lokasi penting dalam perkembangan Kecamatan Sarolangun dari masa pra-kolonial hingga kolonial menarik untuk dibahas. Masifnya pembangunan fasilitas oleh Belanda pada masa kolonial tidak sekedar fokus pada prasarana penunjang transportasi. Pada masa itu, Belanda juga membangun berbagai hunian, perkantoran, gudang, dan prasarana lain. Pengembangan wilayah yang sedemikian rupa tentunya tidak dapat dilepaskan dari adanya pusat kegiatan yang telah ada sebelumnya pada masa pra-kolonial. Sumber daya alam yang dimiliki Sarolangun, terutama emas dan minyak bumi, tentunya menjadi alasan mendasar bagi Belanda untuk membangun pusat di wilayah ini (Andaya, 1993). Sumber daya manusia sebagai pendukung tentunya juga telah berupa komunitas-komunitas. Akan tetapi, sangat disayangkan informasi tentang keadaan masyarakat pada masa pra- kolonial di Kecamatan Sarolangun masih sulit ditelusuri secara mendalam karena keterbatasan data.

Informasi penting lainnya tentang Kecamatan Sarolangun dapat ditelusuri dari laporan Belanda yang menyebutkan tentang penemuan arca ganesha serta reruntuhan bata di Kampung Lubuk, Kecamatan Sarolangun. Lokasi penemuan reruntuhan bata tersebut di atasnya telah dibangun surau atau langgar (Tideman, 1938). Informasi ini menunjukkan bahwa di wilayah Kecamatan Sarolangun telah ada aktivitas manusia sejak masa klasik (HinduBuddha). Selain itu, keberadaan surau atau langgar di atas runtuhan struktur bata juga menunjukkan bahwa pada masa Islam situs ini kembali difungsikan. Informasi tentang situs klasik di Kecamatan Sarolangun hanya didapatkan dari laporan Belanda, karena sampai sejauh ini penelitian tentang situs klasik di Sarolangun belum pernah dilakukan lebih jauh. Aktivitas manusia di sekitar Kecamatan Sarolangun turut diperkuat dengan keberadaan Prasasti Karang Brahi di Pamenang, Kabupaten Merangin yang berasal dari abad ke-7 M (Coedès et al., 2014). Meskipun secara administratif pada masa kini masuk dalam wilayah Kabupaten Merangin, namun secara lokasional kedua wilayah ini berdekatan dan mengindikasikan adanya 
aktivitas manusia setidaknya sejak abad ke$7 \mathrm{M}$.

Fenomena keberadaan situs arkeologi multi-periode pada suatu wilayah dapat ditemui pada berbagai wilayah. Contoh yang ada di Pulau Sumatra, selain di Kecamatan Sarolangun, adalah Kota Jambi dan Kota Palembang. Kota Jambi dan Kota Palembang sejak masa klasik telah menjadi pusat aktivitas manusia. Bukti-bukti aktivitas manusia di Kota Jambi dan Kota Palembang masa klasik dapat ditelusuri berdasarkan tinggalan kebendaan berupa keberadaan struktur bata, arca, prasasti, dan tinggalan artefak lain seperti keramik (Coedès et al., 2014; Saudagar, 1990; Utomo, 1994). Pada masa Islam, beberapa situs dari masa klasik turut dipergunakan kembali, misalnya adalah Candi Sekarabah yang dimanfaatkan sebagai Istana Tanah Pilih dan Candi Gedingsuro yang difungsikan sebagai makam kesultanan. Pada masa kolonial, berbagai situs masa klasik dan Islam kembali dipergunakan, contohnya adalah kawasan Istana Tanah Pilih yang menjadi benteng dan menara air serta Kawasan pusat Kesultanan Palembang yang digunakan kembali sebagai pusat aktivitas pada masa kolonial (Farida et al., 2019; Sukandar, 2014). Contoh lain di luar Indonesia juga dapat ditemui di Singapura dan Mexico City. Situs Fort Canning di Singapura merupakan bukti aktivitas manusia di wilayah Singapura modern sejak masa klasik yang berlanjut hingga masa Islam dan Kolonial (Chandrashekhar, 2017). Kota Mexico modern yang dibangun oleh koloni Spanyol berdiri di atas reruntuhan kota-kota Bangsa Aztec yang sebelumnya telah mendirikan kota-kota kuno (Atwood, 2014). Menilik usaha penelitian dan pelestarian situs-situs di ketiga kota ini dapat menjadi bahan pembanding untuk mengkaji situs-situs Kecamatan Sarolangun serta proyeksi pelestariannya masa kini dan mendatang.

Seperti halnya kota-kota lain, sebagai tempat berlangsungnya aktivitas manusia sejak masa klasik, Kecamatan Sarolangun memiliki berbagai situs arkeologi yang penting untuk diteliti. Selain itu, dibutuhkan hasil penelitian terbaru untuk proyeksi pelestarian situs-situs yang mengandung nilai sejarah di Kecamatan Sarolangun di masa kini dan mendatang. Untuk itu penelitian ini mencoba menelaah situs-situs dari berbagai pembabakan periode yang ada di Kecamatan Sarolangun dari perspektif arkeologi kesejarahan. Poinpoin yang akan dibahas dalam artikel ini antara lain, pertama tentang data situs dan tinggalan Arkeologi di Kecamatan Sarolangun. Kedua, berdasarkan data situs yang ada akan dilakukan analisis terhadap kondisi dan peran wilayah Kecamatan Sarolangun pada masa Klasik, Islam, Kolonial, dan pasca Kemerdekaan. Ketiga, 
berkaitan dengan perkembangan wilayah, pembahasan akan dilakukan terhadap keadaan situs di tengah modernisasi serta peluang pelestariannya.

\section{METODE}

Penelitian ini dilakukan menggunakan perspektif arkeologi kesejarahan (historical archaeology). Kajian arkeologi kesejarahan dipilih atas dasar pembahasan tentang riwayat suatu wilayah yang dibagi dalam pembabakan sejarah (Orser Jr., 2010). Arkeologi kesejarahan juga sering dikaitkan dengan pembahasan mengenai situs-situs arkeologi pada masa kolonialisme dan imperialisme Bangsa Eropa (Falk, 1991; Paynter, 2000). Beberapa ahli lain memahami arkeologi kesejarahan sebagai kajian yang menggabungkan antara data artefaktual dan tekstual, atau antara kata-kata dengan objek (Andrén, 1988; Funari et al., 1999).

Penelitian ini memfokuskan kajian dengan mengamati fenomena-fenomena yang berkaitan dengan situs-situs bukti aktivitas manusia di Kecamatan Sarolangun serta mengaitkannya dengan data sejarah terkait. Fenomena-fenomena ini kemudian dibandingkan dengan wilayah sejenis agar diketahui pola umum dan khusus yang ada pada situs-situs di Kecamatan Sarolangun. Selanjutnya berkaitan dengan modernisasi yang terjadi, akan dibahas pula keadaan situs ditengah arus perubahan yang terjadi beserta peluang serta tantangan pelestariannya. Teknik pengumpulan data dalam penelitian dilakukan dengan survei permukaan, pemetaan potensi, penelusuran terhadap arsip-arsip dan informasi yang berkaitan dengan Kecamatan Sarolangun serta wawancara dengan komunitas Sarolangoen Tempoe Doeleo. Data-data yang telah terkumpul kemudian dianalisis untuk mendapatkan hasil analisis yang mendalam tentang situs-situs di Kecamatan Sarolangun serta peluang dan tantangan pelestariannya.

\section{HASIL DAN PEMBAHASAN}

Situs-situs Arkeologi di Kecamatan Sarolangun

Situs-situs arkeologi yang dipaparkan pada subbab ini berasal dari masa klasik, Islam, dan kolonial yang terlatak di Kecamatan Sarolangun. Mengenai situs-situs pra-klasik (situs-situs prasejarah) di Kecamatan Sarolangun belum dapat ditelusuri keberadaannya. Situs-situs dari masa Prasejarah di sekitar Sarolangun yang diketahui sampai saat ini baru di Kawasan Karst Bukit Bulan yang berlokasi di Kecamatan Limun (Fauzi, 2016; Fauzi et al., 2015; Melisah, 2016). Lokasi situs-situs yang ada di Kecamatan Sarolangun mayoritas berada di bagian tenggara yang terletak pada wilayah sekitar muara atau pertemuan dua sungai (Lihat gambar 1). Terdapat fenomena keberadaan 
pusat-pusat aktivitas manusia yang berkaitan dengan daerah pertemuan dua sungai. Umumnya lokasi pertemuan dua sungai atau muara menjadi lokasi situs arkeologi. Fenomena aktivitas manusia di daerah pertemuan dua sungai juga didukung oleh teori Bennet Bronson yang mengemukakan bahwa daerah pertemuan dua sungai di berbagai wilayah Asia Tenggara merupakan tempat berlangsungnya kegiatan pertukaran barang dan jasa yang kemudian memunculkan pusat aktivitas manusia dan berkembang menjadi kota-kota besar (Bronson, 1977). Untuk mendapatkan gambaran secara kronologis maka pemaparan pada subbab ini akan dilakukan secara kronologis mulai dari masa klasik, Islam, kolonial, hingga informasi tentang keadaan situsnya pada masa kini.

Gambar 1. Wilayah Kecamatan Sarolangun (Sumber: Tim Penulis, 2020).

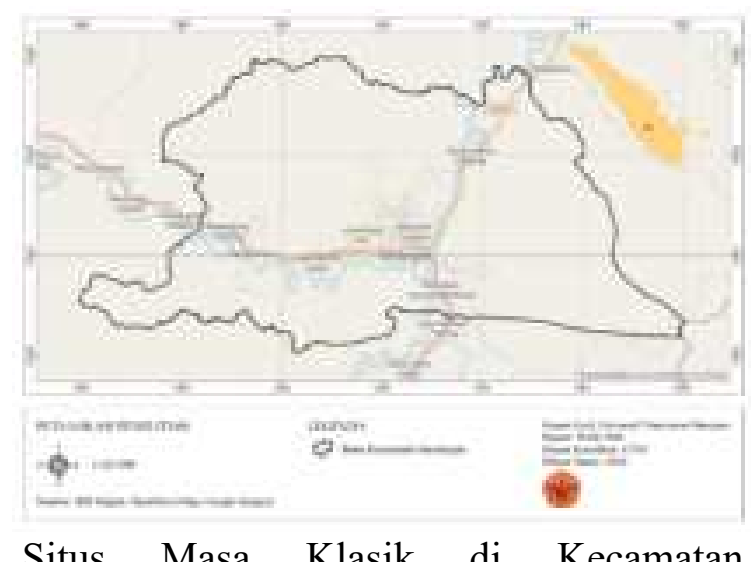

Sarolangun

Sesuai dengan informasi yang telah disinggung pada bagian pendahuluan, keberadaan situs masa klasik di Kecamatan Sarolangun telah dilaporkan oleh Belanda. Temuan-temuan tersebut terdiri dari arca ganesha, arca lain yang telah hilang (dalam Laporan Belanda tidak disebutkan alasan hilangnya arca ini), serta struktur bata yang berada di bawah Surau Kampung Lubuk. Arca ganesha yang disebutkan dalam laporan Belanda sekarang berada di Museum Sultan Mahmud Badaruddin II dengan label arca ganesha Surulangun (Utomo, 2016). Mengenai struktur bata yang terdapat dalam laporan sekarang berubah menjadi Langgar Jannatul Khoir. Hasil dari pengamatan lapangan menunjukkan di sekitar langgar tersebut terdapat temuan bata. Temuan lepas berupa bata berukuran besar terletak di sekitar pondasi langgar serta di bawah rumah panggung di samping surau (Lihat gambar 1). Selain temuan bata, di sekitar langgar juga ditemukan fragmen tembikar dan keramik (Lihat gambar 2 dan 3). Berdasarkan bentuk dan warnanya, diperkirakan keramik berasal dari masa Dinasti Sung, yaitu abad ke-10 sampai 13 Masehi. Menurut informasi dari narasumber, selain temuan lepas yang ada di sekitar langgar, terdapat susunan bata yang masih intact di bawah pondasi langgar. 

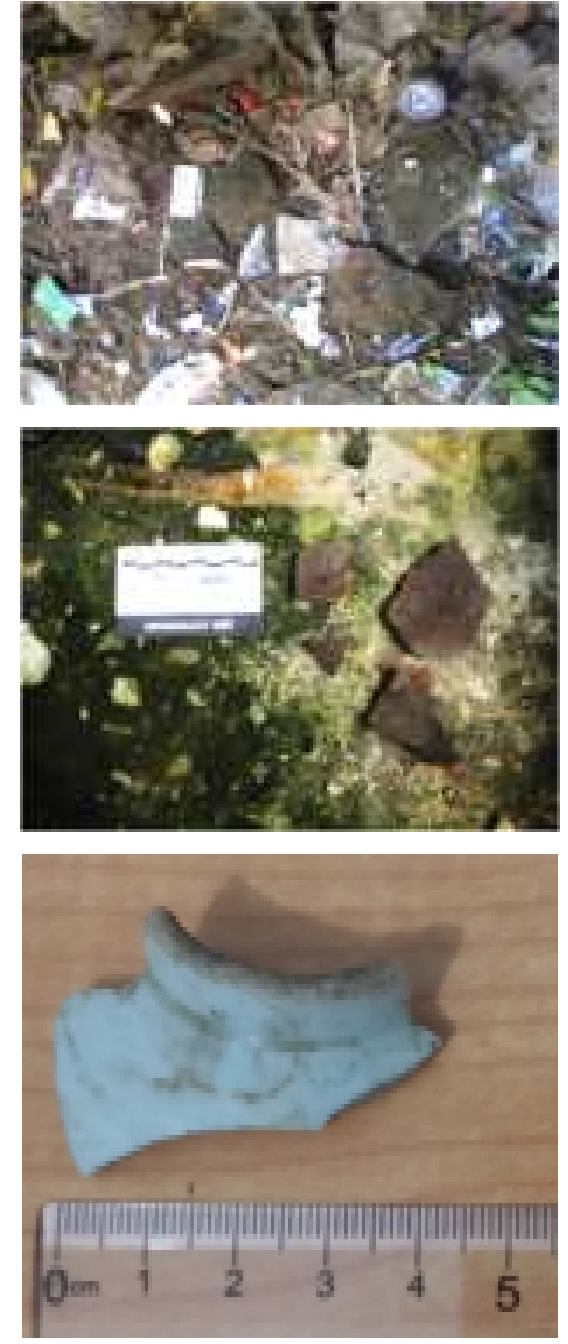

Gambar. 2, 3, dan 4. Fragmen Bata di Sekitar Langgar (atas); Fragmen Tembikar (tengah); Fragmen Keramik (bawah) (Sumber: Dokumentasi Tim Penulis, 2020).

Selain situs yang telah dilaporkan Belanda, terdapat satu situs lagi yang diindikasikan mengandung tinggalan dari masa klasik. Situs tersebut terletak di Pemakaman Muara Sawah. Pemakaman Muara Sawah merupakan kompleks makam Islam yang terdiri atas fosil kayu (batu sungkai) yang digunakan sebagai nisan dan batu bata berukuran besar yang dimanfaatkan sebagai pembatas makam (Lihat gambar 5). Jumlah temuan permukaan berupa bata di Pemakaman Muara Sawah lebih banyak dibandingankan dengan yang ada di Langgar Jannatul Khoir. Bata-bata tersebut terdiri dari fragmen bata, bata yang utuh, dan bata kuncian (Lihat gambar 6). Bata kuncian merupakan bentuk bata berlekuk yang biasanya digunakan secara berpasangan sebagai kunci untuk memperkuat susunan bata. Mengenai kronologi situs Pemakaman Muara Sawah belum dapat ditentukan karena data-data yang ditemukan belum dapat memberikan petunjuk kronologinya. Berdasarkan kategorinya, kuat indikasi kedua situs ini sebelumnya merupakan situs sakral. Indikasi ini didukung dengan informasi temuan Arca Ganesha dan pemanfaatan ulangnya sebagai tempat sakral dalam agama Islam.
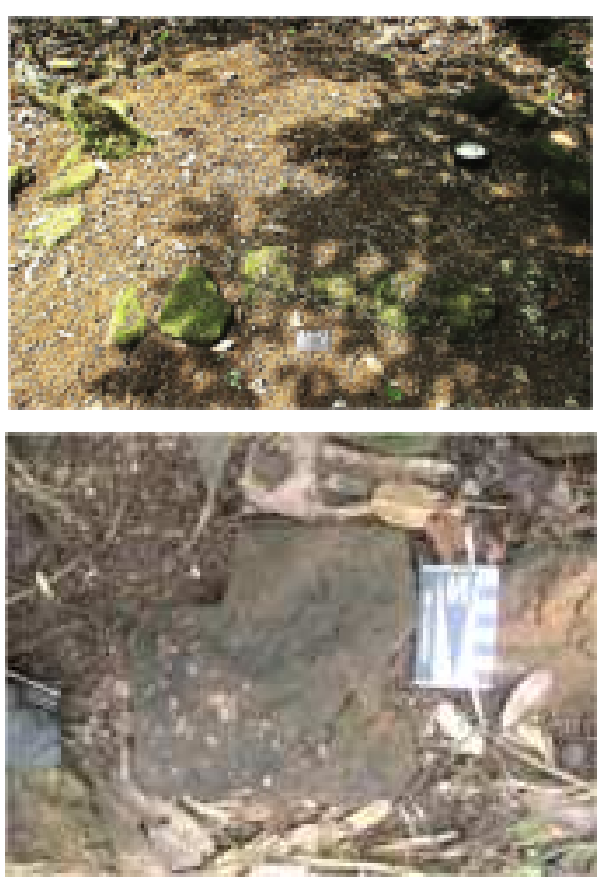

Gambar 5 dan 6. Bata dan Batu Sungkai (atas) dan Bata Kuncian (bawah) (Sumber: Dokumentasi Tim Penulis). 
Situs Masa Islam di Kecamatan Sarolangun

Menyambung paparan data tentang situs-situs masa Klasik, kedua situs yang telah dibahas juga dapat dikategorikan sebagai situs Masa Islam. Surau Kampung Lubuk atau yang setelah direnovasi disebut Langgar Jannatul Khoir berada di Kampung Lubuk. Selain itu terdapat makam tokohtokoh lokal yang berjasa di Kecamatan Sarolangun, yaitu Makam Putri Darah Putih dan Makam Bujang Kurap yang berlokasi di Kelurahan Gunung Kembang. Sayangnya petunjuk mengenai kronologi masa hidup kedua tokoh dan situs makam belum dapat diketahui secara pasti. Ditambah lagi, berdasarkan kunjungan yang telah dilakukan temuan dua makam tersebut hanya berupa nisan batu sungkai yang tidak berangka tahun dan belum ada temuan lain yang mengindikasikan keberadaan struktur atau sisa aktivitas manusia dimasa lampau.

Kampung Lubuk menurut informasi narasumber merupakan kampung tertua yang ada di Sarolangun. Kampung Lubuk berada di tepi aliran sungai. Masyarakatnya terdiri dari etnis Melayu yang beragama Islam. Berdasarkan pengamatan yang dilakukan di Kampung Lubuk, perbatasan antara Kampung Lubuk dan daerah Pasar Sarolangun sekaligus menjadi pembatas antara hunian etnis Melayu dan orang-orang Eropa. Hal ini antara lain terlihat berdasarkan perbedaan arsitektur bangunan-bangunan tua. Di Kampung Lubuk, bangunan tua terdiri dari hunian berbentuk rumah panggung sedangkan di sekitar pasar didominasi oleh bangunan panggung bergaya Indis yang kental unsur-unsur Eropanya. Keadaan Kampung Lubuk sedemikian rupa mengindikasikan keberadaan hunian pascaklasik yang ditinggali oleh Etnis Melayu dan kemudian turut ditinggali oleh Bangsa Eropa (Melisah, 2016).

$$
\text { Sejalan dengan indikasi }
$$
penggunaan ulang bangunan masa klasik pada masa Islam di Surau Kampung Lubuk, Pemakaman Muara Sawah juga diindikasikan sebagai situs klasik yang difungsikan ulang pada masa Islam. Kuat indikasi latar belakang pemanfaatan ulang situs ini terkait dengan pandangan tentang titik sakral terhadap lokasi tersebut. Pemakaman Muara Sawah sekarang tidak digunakan lagi sebagai tempat pemakaman. Bahkan makam-makam tua yang ada disana, mayoritas tidak dirawat dan tidak diketahui lagi identitas orang-orang yang dimakamkam. Menurut informasi dari narasumber, salah satu tokoh yang dimakamkan di Muara Sawah adalah Puyang Jenggot. Puyang Jenggot dikenal sebagai sesepuh atau tetua kampung. Berdasarkan kategorinya, situs masa klasik yang difungsikan kembali pada masa Islam keduanya merupakan bangunan sakral, 
yaitu surau yang digunakan sebagai tempat ibadah dan pemakaman Islam. Penggunaan ulang situs ini memperkuat indikasi keberlanjutan pandangan tentang ruang sakral masa Klasik yang berlanjut sebagai ruang sakral pada masa Islam di Kecamatan Sarolangun.

\section{Situs Masa Kolonial di Kecamatan Sarolangun}

Pembangunan fasilitas fisik oleh Belanda di Kecamatan Sarolangun tidak lepas dari runtuhnya pemerintah Kesultanan Jambi. Sejak dibakarnya Istana Tanah Pilih pada 1858, Belanda memegang peranan penting dalam berbagai kebijakan dan struktur pemerintahan di Jambi. Dihapuskannya sistem kesultanan pada 1901 menjadikan sebagian besar wilayah Jambi berada di bawah kendali penuh Pemerintah Kolonial Hindia-Belanda di bawah Asisten Residen yang bertanggungjawab kepada Karesidenan Palembang (Lindayanti, 2014; Miftahurrahmat, 2018). Pada saat itu, Belanda mulai membangun berbagai sarana untuk menunjang kehidupan di Kecamatan Sarolangun. Sketsa tentang fasilitas kolonial di Kecamatan Sarolangun pernah dibuat J.E.H Boomgard, namun sebagian besar telah hancur. Lenyapnya bangunan-bangunan Belanda ini disebabkan adanya peristiwa penghancuran oleh penduduk sipil tahun 1947 (Melisah, 2016).
Asisten Residen Jambi secara resmi berubah menjadi Karesidenan Jambi pada 1906. Kecamatan Sarolangun pada saat itu bernama Onderdistrict Sarolangun yang merupakan pusat administrasi dari Afdeeling Sarolangoen. Selain Onderdistrict Sarolangun, Afdeeling Sarolangoen juga membawahi Onderdistrict Limoen, Onderdistrict Batangasai, dan Onderdistrict Pauh (Tideman, 1938). Di bawah Onderdistrict Sarolangun masih terbagi menjadi tiga wilayah administratif setingkat Marga, yaitu: Marga Sarolangun, Marga Pelawan, dan Marga Batin VIII. Dasar hukum pembagian itu adalah IGOB (Inlandsche Gemente Ordonatie Buitengewesten), sebuah regulasi yang mengatur bentuk pemerintahan Hindia-Belanda di luar Jawa (Hidayat, 2012). Dengan adanya pembentukan administrasi semacam ini, Belanda semakin gencar membangun fasilitas fisik di Kecamatan Sarolangun. Situs-situs masa kolonial yang masih tersisa dari aktivitas tersebut antara lain berupa jembatan, makam (kerkhof), kantor, bak air, gudang, benteng, prasasti kapal karam, serta hunian.

Jembatan Beatrix seperti yang telah disinggung pada bagian pendahuluan, menurut prasasti yang ada di ujung jembatan, dibangun sejak tahun tahun 1932 dan selesai pada tahun 1939. Jembatan 
Beatrix saat ini masih dapat dilalui oleh kendaraan roda 2 dan 4, namun tidak lagi menjadi penghubung utama (Lihat gambar 9). Fungsi Jembatan Beatrix sebagai jembatan utama telah digantikan oleh Jembatan Sarolangun yang terletak sekitar 500 meter sebelah timur Jembatan Beatrix.

Berdasarkan pengamatan lapangan letak Jembatan Sarolangun sekarang membelah Pasar Sarolangun dan berada pada dekat simpang tiga jalan lintas ke arah Jambi, Sumatra Selatan, dan Merangin. Letak Jembatan Beatrix berada di sebelah barat berdekatan dengan Kampung Lubuk. Letak kedua jembatan ini menunjukkan keberadaan jalur lama yang berada dekat dengan pemukiman tua dan jalur baru yang dibangun berdasarkan jalur lintas penghubung kota-kota di Jambi dan Sumatra Selatan.

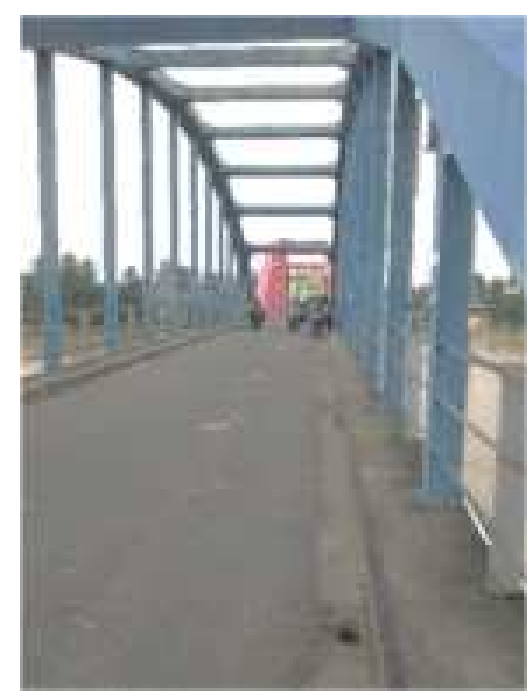

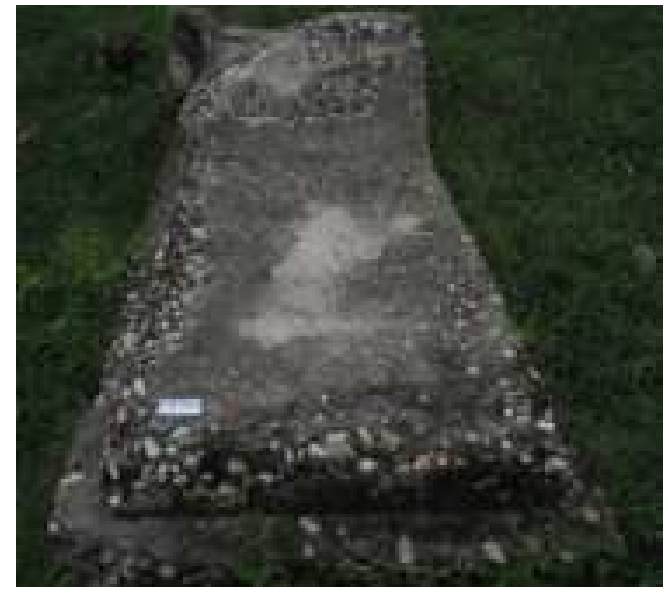

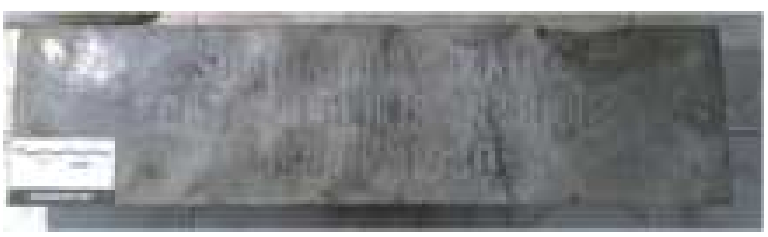

Gambar 7, 8, dan 9. Jembatan Beatrix (bawah kiri); Salah satu Makam di dekat Jembatan Sarolangun (atas); Batu Nisan Berangka Tahun 1930 (bawah) (Sumber: Dokumentasi Nainunis Aulia Izza, 2019).

Pengalihan jalur utama ini juga dapat dilihat dari keberadaan makam Belanda (kerkhof) yang sebagian besar bagiannya tergusur dan berubah menjadi jalan. Sisa-sisa kerkhof antara lain dapat ditelusuri melalui keberadaan 2 makam yang sekarang terletak di semak-semak taman dekat Jembatan Sarolangun (Lihat gambar 10). Sisa-sisa prasasti makam yang sekarang disimpan oleh narasumber menunjukkan penanggalan kematian orang yang dimakamkan pada tahun 1930 (Lihat gambar 11). Berdasarkan arsip dan catatan perdagangan Belanda, wilayah Sarolangun memang baru dijadikan kawasan hunian Belanda sejak awal abad ke-20 (Melisah, 2016). Periodisasi ini jauh lebih muda apabila dibandingkan dengan kerkhof di 
kawasan lain seperti Batavia yang berdasarkan angka tahun dalam prasastinya umumnya berasal dari abad ke 16 (Suratminto, 2008). Situs-situs masa kolonial lain yang masih tersisa antara lain bak air yang ada di sekitar Pasar Sarolangun, sisa lantai dan pondasi gudang garam yang sekarang masuk dalam kompleks Sekolah Dasar Negeri 1 Sarolangun, tugu benteng yang terpahat pada tugu di sudut kompleks pertokoan Pasar Sarolangun, dan Prasasti Kapal Karam Ophelia yang sekarang telah aus, letaknya berada di dekat kerkhof (Lihat gambar 10, 11, 12, 13). Diantara situs-situs yang tersisa tersebut keadaannya sekarang tidak lagi terawat, misalnya prasasti benteng yang sekarang justru menjadi tempat membuang sampah (Lihat gambar 12).
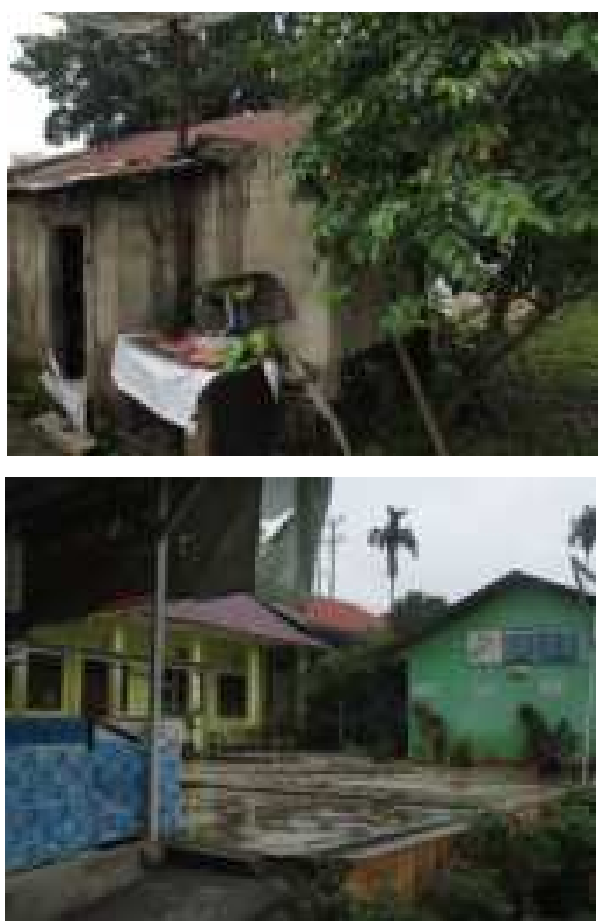
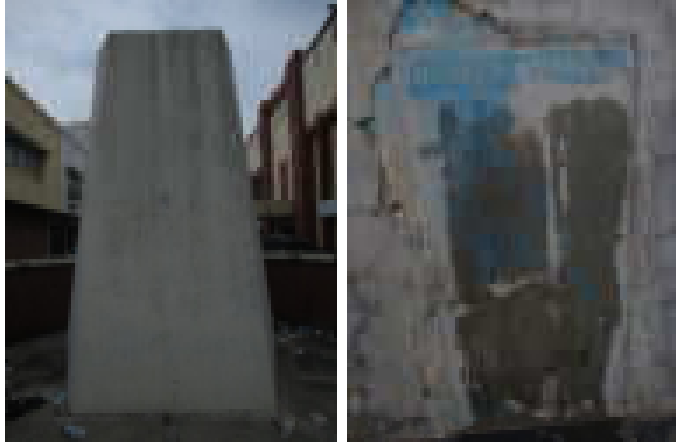

Gambar 10, 11, 12, dan 13. Bak Air di Sekitar Pasar Sarolangun (kiri bawah atas); Sisa Lantai dan Pondasi Gudang Garam di Kompleks SDN 1 Sarolangun (kiri bawah); Tugu Benteng yang Penuh Sampah (atas kiri); Prasasti Kapal Karam Ophelia yang telah Aus (kanan atas)(Sumber: Dokumentasi Nainunis Aulia Izza, 2019).

\section{Kecamatan Sarolangun Masa Klasik,} Islam, Kolonial, dan Pasca

\section{Kemerdekaan}

Dari pemaparan tentang situs-situs masa klasik, Islam, dan kolonial di Kecamatan Sarolangun di atas, diperoleh adanya fenomena situs multi periode yang terpusat di Kota Sarolangun sekarang. Fenomena tersebut dapat digunakan sebagai dasar analisis dan sintesis mengenai peran wilayah Kecamatan Sarolangun pada masa Klasik, Islam, Kolonial, hingga masa kini. Sebagaimana situs-situs klasik lain di Pulau Sumatra, situs-situs klasik di Kecamatan Sarolangun berada di dekat aliran sungai utama, tepatnya di dekat pertemuan dua sungai. Hal ini mengindikasikan wilayah Kecamatan Sarolangun merupakan salah satu pusat aktivitas manusia pada masa klasik. Jenis arca-arca yang pernah ditemukan di 
Kecamatan Sarolangun mengindikasikan adanya pengaruh Agama Hindu khususnya aliran Siwa. Hal ini agak kontras dengan temuan situs klasik lain di sepanjang Sungai Batanghari yang berkarakter Agama Budha. Temuan arca Ganesha setengah jadi di wilayah ini juga memperkuat indikasi keberadaan masyarakat beragama HinduSaiwa yang melaksanakan berbagai kegiatan sakral di sekitar Kecamatan Sarolangun (Utomo, 2016). Tinggalan monumental berupa Candi Lesung Batu yang memiliki yoni memperkuat bukti keberadaan komunitas masyarakat beragama Hindu aliran Siwa di sekitar Sarolangun dan Musi Rawas Utara (Sedyawati et al., 2014). Ditinjau berdasarkan cakupan wilayah yang lebih luas, tinggalan Prasasti Karang Berahi, Candi Tingkip, Candi Lesung Batu, dan temuan bata-bata candi di Kecamatan Sarolangun menunjukkan keberadaan komunitas Hindu-Buddha di sekitar Kecamatan Sarolangun. Namun, terkait dengan hubungan antara situs-situs tersebut masih belum dapat ditentukan dan membutuhkan penelitian yang lebih mendalam.

Memasuki masa Islam, fenomena yang tampak adalah penggunaan kembali lokasi situs-situs Klasik di Kecamatan Sarolangun sebagai tempat sakral umat Islam, yaitu surau dan makam. Keberadaan tinggalan masa Islam juga menunjukkan kesamaan lokasi pusat aktivitas manusia di Kecamatan Sarolangun pada masa lalu. Fakta keberlanjutan lokasi aktivitas manusia ini belum dapat diketahui secara pasti faktor penyebabnya. Akan tetapi terdapat dua asumsi yang kemungkinan dapat menjawab permasalahan ini. Asumsi pertama adalah adanya proses konversi kepercayaan pada komuniatas masyarakat di Kecamatan Sarolangun, sedangkan asumsi kedua adalah komunitas masyarakat yang mendiami daerah tersebut berbeda dengan komunitas yang ada pada masa Klasik.

Mengenai kemungkinan pertama, tentang konversi kepercayaan, terdapat informasi pembanding yang ada di Jawa. Pada masa awal perkembangan Islam di Jawa, terdapat pola penggunaan kembali lokasi bangunan sakral dari masa Klasik sebagai sarana peribadatan umat Islam. Salah satu contohnya adalah pembangunan Masjid Mantingan yang bahan-bahan pembangun masjidnya berasal dari bangunan suci berkarakter Hindu, dibuktikan dengan adanya potongan relief Ramayana (Munandar, 1999). Selain penggunaan kembali lokasi bangunan suci Klasik, terdapat indikasi pembangunan masjid mirip dengan candi masa Klasik. Usaha pemiripan bangunan suci ini dapat dihubungkan dengan misi menarik minat dan ingatan kolektif masyarakat agar tetap datang ke lokasi dan bangunan yang 
dianggap sakral, meskipun latar keagamaan bangunan tersebut berbeda (Rosyid, 2019).

Berkaitan dengan kemungkinan perbedaan komunitas yang mendiami Kecamatan Sarolangun, terdapat beberapa bukti dalam catatan sejarah yang mendukung. Salah satunya adalah adanya migrasi masyarakat Minangkabau dari Pagaruyung ke wilayah Sarolangun. Awal mula kedatangan masyarakat Minangkabau ke wilayah Sarolangun adalah karena daya tarik sumber emas yang ada di daerah sekitar aliran sungai Batang Asai dan Batang Limun. Hal ini mendorong orangorang Minangkabau untuk datang dan bermigrasi ke daerah ini, kemudian menetap dan menjadi bagian dari penduduk Sarolangun (Scholten, 2008). Faktor lain yang mendorong adanya migrasi ini adalah akibat kekalahan Aceh oleh VOC pada 1667. Hal ini kemudian mengakibatkan bertambahnya jumlah orang Minangkabau yang bermigrasi (rantau) ke Sarolangun dan wilayah Jambi lainnya, baik yang kemudian menetap maupun hanya sebagai pekerja lepas. Hal ini ditandai dengan bertambahnya jumlah tambang emas di Sarolangun, Jujuhan, Tabir, Tebo dan Hulu Sungai Tembesi. Pada 1688, seorang pejabat VOC mendeskripsikan salah satu distrik di Hulu Sungai Batanghari, sekitar dua minggu perjalanan dari Jambi. Di sini terdapat beberapa ribu orang yang datang secara musiman untuk mencari emas. Terutama pada musim penghujan, karena emas akan mudah ditemukan di tanah dan aliran-aliran sungai setelah terjadi hujan lebat (Andaya, 1993).

Komunitas orang Minangkabau telah tinggal menetap di berbagai sudut Sarolangun sejak lebih dari lima ratus tahun lalu. Penyebaran orang-orang dari daerah Minangkabau ke Sarolangun dilakukan dengan cara berkelompok, tidak hanya membawa orang-orangnya saja, tetapi sekaligus memboyong adat kebiasaan, hukum, norma-norma, nilai-nilai dan berbagai bentuk organisasi sosial mereka, termasuk teknologi mata pencarian baru yaitu menambang emas (Naim, 1982). Pada tahun 1740 penambang emas dari Minangkabau meminta Kesultanan Jambi agar membuka Sarolangun dan Limun sebagai kawasan penambangan emas bagi mereka (Andaya, 1993). Mereka menjadi satu-satunya golongan masyarakat yang menggali tambang emas atau mengumpulkannya di aliran sungai. Sementara itu aktivitas para penduduk asli terpusat pada produksi pangan untuk suplai logistik para pencari emas. Dinamika tersebut tampaknya berlaku di Limun, Batang Asai dan Pakalang Jambu yang merupakan tempat perdagangan emas yang tergolong cukup ramai (Marsden, 2013). 
Pada tahun 1728 jumlah orang yang datang dari Minangkabau ke kawasan hulu Jambi, dengan tujuan menambang emas, lebih banyak lagi, dan hampir mencapai 1000 orang. Mereka tersebar dalam 15 sampai 20 orang di setiap kampung (Andaya, 1993). Mereka melakukan penambangan dengan teknologi yang sederhana, baik dengan cara membuat parit atau dengan cara menggunakan kincir. Selain mencari emas, mereka juga menanam lada. Pekerjaan menambang emas menjadi pekerjaan utama saat musim kemarau sembari menunggu panen, sedangkan pada saat musim hujan mereka melakukan pekerjaan sampingan seperti mencari dan berdagang rempah-rempah (Kozok, 2015).

\section{Selanjutnya tentang Kecamatan} Sarolangun masa kolonial, berdasarkan kepadatan tinggalannya merupakan salah satu pusat hunian dan kegiatan orang-orang Eropa. Lokasi-lokasi yang mirip dengan Kecamatan Sarolangun salah satunya adalah Muara Tembesi. Akan tetapi, terdapat perbedaan yang cukup mencolok dengan Kecamatan Muara Tembesi. Kecamatan Sarolangun sekarang tetap menjadi pusat kegiatan (ibukota kabupaten), sedangkan Muara Tembesi sekarang bukan lagi pusat kegiatan ekonomi dan pemerintahan di Kabupaten Batanghari (Syuhada et al., 2017). Keberadaan Jembatan Beatrix di sekitar
Kampung Lubuk dan hunian Eropa menunjukkan Kecamatan Sarolangun merupakan tempat strategis dalam perspektif planologi Belanda. Hal ini didasarkan pada pola pembangunan Belanda di Sumatra yang hanya berpusat di wilayah-wilayah yang dianggap strategis. Wilayah-wilayah yang dianggap strategis oleh Belanda di Pulau Sumatra bagian selatan antara lain adalah Sumatra Barat dan Sumatra Selatan. Bukti perhatian pemerintah Hindia-Belanda pada kedua wilayah ini diantaranya adalah usaha pembangunan jalur transportasi darat, berupa jaringan jalan darat (landwegen) dan jalur perkeretapian (Asnan, 2002). Selain itu, pada awal abad ke-20, Kota Padang diberi status sebagai gemeente (kota praja) oleh pemerintah Hindia-Belanda (Sujiyati \& Ali, 2015; Zed, 2009). Dikaitkan dengan wilayah Kecamatan Sarolangun, perannya bukan hanya sebagai titik tengah wilayah dataran tinggi dan dataran rendah di Jambi, namun juga penghubung dua kota besar masa Kolonial, yaitu Padang dan Palembang.

Pasca Kemerdekaan Indonesia, walaupun bangunan-bangunan peninggalan Belanda di Kecamatan Sarolangun dihancurkan, namun posisinya sebagai salah satu pusat aktivitas manusia tetap berlanjut. Sejak masa Orde Lama, Orde Baru, sampai dengan awal masa reformasi terjadi berbagai perubahan status 
administrasi wilayah Kecamatan

Sarolangun. Pasca Kemerdekaan,

Kecamatan Sarolangun termasuk dalam wilayah Jambi Ilir dan mulai tahun 1990 sampai 1999 menjadi bagian dari Kabupaten Sarolangun Bangko. Dengan adanya Undang-Undang Nomor 5 tahun 1979, Sistem Pemerintahan Marga juga kemudian dihapus dan digantikan dengan sistem pemerintahan desa. Sejak tahun 1999 atau pasca reformasi terjadi pemekaran wilayah yang sekaligus memecah Kabupaten Sarolangun Bangko menjadi Kabupaten Sarolangun dan Kabupaten Bangko (Website Resmi Kabupaten Sarolangun). Setelah menjadi kabupaten, Kecamatan Sarolangun menjadi ibukota Kabupaten Sarolangun. Berdasarkan uraian di atas posisi wilayah Kecamatan Sarolangun sejak masa HinduBuddha sampai dengan masa kini merupakan pusat aktivitas manusia masa lalu. Terjadinya aktivitas manusia dalam kurun waktu lama menyebabkan tinggalan yang ada di Kecamatan Sarolangun saling tumpang tindih.

\section{Situs Arkeologi dan Perkembangan}

\section{Modernisasi di Kecamatan Sarolangun}

Seiring dengan perkembangan zaman, modernisasi pada berbagai wilayah tidak dapat dielakkan. Terdapat wilayahwilayah yang berkembang pesat seiring zaman, selain itu ada berbagai wilayah yang dikembangkan serta ditinggalkan. Lokasi Kecamatan Sarolangun yang sekarang menjadi ibukota Kabupaten Sarolangun mendorong modernisasi dan pembangunan sarana fisik yang pesat dewasa ini. Apabila dibandingkan dengan kota-kota lain di Sumatra, perkembangan Kecamatan Sarolangun mirip dengan perkembangan Kota Jambi dan Kota Palembang.

Ditinjau dari perspektif arkeologi, baik Kota Jambi dan Kota Palembang memiliki situs-situs arkeologi dari masa Klasik. Situs-situs tersebut terletak di tepi Sungai Batanghari dan Musi yang menjadi pusat aktivitas manusia sejak masa lampau hingga sekarang. Percandian Solok Sipin di Kota Jambi merupakan bukti adanya aktivitas masyarakat pada masa klasik di sekitar pasar dan pusat kota Jambi modern. Percandian Solok Sipin yang terdiri dari 4 runtuhan bangunan yang tersebar di sekitar tepi Sungai Batanghari sampai Danau Sipin. Pada masa Islam, salah satu lokasi, yaitu Candi Sekarabah dijadikan lokasi pembangunan Istana Kesultanan Jambi, yaitu Istana Pilih Pusako Bertuah. Sejak penyerangan Belanda tahun 1858, istana tersebut runtuh kemudian lokasi pendirian istana diubah sebagai benteng dan markas tentara Belanda. Setelah Indonesia merdeka, markas lokasi yang sama digunakan sebagai markas TNI dan setelah itu pada lokasi yang sama pada tahun 1970- 
an dibangun Masjid Al Falah atau yang dikenal sebagai Masjid Seribu Tiang (Sukandar, 2014). Sementara situs-situs candi di sekitarnya sekarang telah berubah menjadi pemakaman Islam masa kesultanan serta pemukiman padat penduduk. Begitupun di Kota Palembang, wilayah tempat penemuan artefak masa klasik, misalnya Situs Gedingsuro di Kota Palembang dipergunakan kembali pada masa Islam dan berada pada wilayah yang sama dengan pusat pemerintahan kolonial serta pusat Kota Palembang dewasa ini (Utomo, 2016). Diantara situs-situs tersebut banyak yang telah berubah menjadi pemukiman dan pabrik.

Kota Jambi dan Kota Palembang dewasa ini masing-masing merupakan ibukota provinsi yang menjadi pusat ekonomi, pemerintahan, politik, dan kebudayaan. Kecamatan Sarolangun yang sekarang menjadi ibukota kabupaten memang belum mengalami modernisasi semasif Kota Jambi dan Palembang, namun cepat atau lambat Kecamatan Sarolangun akan mengalami berbagai perubahan fisik sarana dan prasarana. Apabila dikorelasikan dengan situs arkeologi yang ada, perlu dilakukan pendataan, penelitian, serta usaha pelestarian. Contoh usaha untuk melestarikan situs arkeologi di lokasi kota besar telah dilakukan di Singapura dan Mexico City. Situs arkeologi masa klasik, Islam, dan kolonial di Fort Canning,
Singapura memiliki kemiripan pola perkembangan dengan situs-situs yang ada di Sarolangun, Kota Jambi, dan Kota Palembang. Mengenai pembahasan tentang pola perkembangan kota perlu dilakukan penelitian tersendiri yang lebih mendalam. Sedangkan mengenai usaha perlindungan ditengah modernisasi usaha yang dilakukan Singapura dapat dijadikan contoh. Situs Fort Canning dewasa ini berada di tengah kota dan menjadi Ruang Terbuka Hijau (Chandrashekhar, 2017). Sisa-sisa struktur bata yang sebagian sudah digali diubah menjadi museum situs. Makam keramat, terowongan, serta sisa benteng yang tersebar di wilayah situs diubah menjadi tempat wisata kota yang berada diantara taman-taman.

Di Mexico City, terdapat situs-situs Pra-Kolombia yang pernah didirikan oleh Bangsa Aztec. Situs-situs yang telah dikuasai dan dihancurkan Spanyol pada paruh kedua abad ke-16 dan baru diteliti kembali sekitar tahun 1970-an (Atwood, 2014). Situs-situs masa Aztec di Mexico City saat ini hanyalah tinggal puing-puing yang tersebar di bawah bangunanbangunan modern. Bahkan, Katedral Mexico City berdiri di atas kuil Aztec yang disebut Templo Mayor. Usaha preservasi dan penelitian terhadap Templo Mayor dilakukan tanpa merusak bangunan katedral, melainkan dengan merekonstruksi 
dan memvisualisasikannya dengan bantuan teknologi digital (Serrato-Combe, 2003).

Dihubungkan dengan situs-situs yang berada di Kecamatan Sarolangun, baik situs klasik yang dipergunakan kembali pada masa Islam sampai kini maupun situs kolonial yang sekarang telah dihancurkan dan di atasnya terdapat bangunan baru dapat dilestarikan seperti yang terjadi di Singapura dan Meksiko. Situs-situs yang ada di Kecamatan Sarolangun seluruhnya berada di wilayah kota yang ramai. Di sekitar Jembatan Beatrix juga sudah dibuat taman terbuka yang bernama Taman Tepian Cik Minah. Pengembangan taman dapat dilakukan di berbagai situs klasik dan kolonial agar masyarakat dan wisatawan yang berkunjung ke Sarolangun dapat mengenal riwayat Sarolangun.

Di luar Kecamatan Sarolangun, situs-situs arkeologi lain tentu saja mungkin ditemukan. Akan tetapi tantangan yang dihadapi saat ini di wilayah Sarolangun pada umumnya adalah keberadaan Penambangan Emas Tanpa Izin (PETI). Penambangan emas yang dilakukan oleh masyarakat di kawasan Sarolangun memang telah ada sejak ratusan tahun lalu, akan tetapi bersifat fluktuatif. Ada kala intensitasnya meningkat dan adakalanya menurun. Penambangan emas yang bersifat fluktuatif tersebut dipengaruhi oleh perubahan kondisi sosial, politik dan ekonomi. Pada periode 1970-1999, masyarakat kebanyakan bekerja sebagai penyadap karet, mencari hasil hutan dan petani. Walaupun demikian, pekerjaan sebagai penambang emas masih tetap berjalan dengan intensitas dan skala yang kecil (Arifin, 1986). Pada tahun 2000 aktivitas penambangan emas kembali marak karena harga karet anjlok. Pola dan teknik penambangan mengalami perubahan dari masa sebelumnya. Perubahan tersebut didorong oleh kemajuan dalam teknologi penambangan. Penambangan dilakukan menggunakan mesin penyemprot dan mesin penghisap atau lazim disebut dengan dompeng, berasal dari merk mesin diesel dong feng. Penggalian juga dilakukan secara masif menggunakan alat berat sehingga dianggap merusak lingkungan karena membabat habis hutan dan vegetasi di permukaannya, termasuk kemungkinan situs-situs arkeologi yang belum terdeteksi.

\section{PENUTUP}

Di Kecamatan Sarolangun terdapat berbagai situs yang berasal dari masa klasik, Islam, dan kolonial. Keberadaan situs-situs ini menandakan eksistensi wilayah yang sekarang menjadi Kecamatan Sarolangun sejak masa klasik hingga sekarang sebagai pusat aktivitas manusia. Pola perkembangan Kecamatan Sarolangun mirip dengan Kota Jambi dan Kota 
Palembang yang merupakan dua kota besar di Sumatra. Di tengah modernisasi perlu dilakukan kajian dan preservasi agar situs yang ada sekarang tidak hilang dan terlupakan. Berkaitan dengan hasil penelitian yang telah dilakukan terdapat beberapa peluang penelitian yang dapat didalami berkaitan dengan Kecamatan Sarolangun. Peluang tersebut antara lain adalah tinjauan korelasi antara temuan berlatar Hindu di Kecamatan Sarolangun dan Situs Lesung Batu. Selain itu, berkaitan dengan konsep-konsep yang melandasi pola perkembangan kota-kota di Sumatra dan Semenanjung Melayu perlu dilakukan penelitian yang lebih mendalam.

\section{UCAPAN TERIMA KASIH}

Ucapatan terima kasih tim penulis ucapkan kepada Universitas Jambi sebagai pemberi dana penelitian dan dukungan persuratan serta Dinas Pendidikan dan Kebudayaan Kabupaten Sarolangun atas yang telah memberikan izin penelitian kepada penulis. Tak lupa penulis ucapkan terima kasih para mahasiswa dan alumni Program Studi Arkeologi, Universitas Jambi, yaitu Rahman Saputra, Najla Anggraini, dan Dini Azhari. Penulis juga mengucapkan terima kasih Bapak Hermanto B.S selaku penggiat sejarah Sarolangun dan sebagai narasumber dalam penelitian ini.

\section{DAFTAR PUSTAKA}

Andaya, B. W. 1993. To Live as Brothers: Southeast Sumatra in the Seventeenth and Eighteenth Centuries. University of Hawai'i Press.

Andrén, A. 1988. Between Artifacts and Texts: Historical Archaeology in Global Perspective. Plenum Publishing.

Arifin, M. 1986. Sistem Ekonomi Tradisional Daerah Jambi. Departemen Pendidikan dan Kebudayaan proyek Inventarisasi dan dokumentasi Kebudayaan Daerah.

Asnan, G. 2002. Transportation on the West Coast of Sumatra on the Nineteenth Century. In Bijdragen tot de Taal-, Land-en Volkenkunde (On The Roa, hal. 727-741).

Atwood, R. 2014. Under Mexico City. Archaeology, 67(4), 26-33.

Bronson, B. 1977. Exchange at the Upstream and Downstream Ends: Notes towards a Functional Model of the Coastal State in Souteast Asia. In K. L. Huterrer (Ed.), Economic Exchage and Social Interaction in Southeast Asia: Perspective from Prehistory, History and Ethnography (hal. 39-52). University of Michigan. 
Chandrashekhar, V. 2017. The Lion City's Glorious Part. Archaeology, 70(6), 61-63.

Coedès, G., Damais, L.-C., Kulke, H., \& Manguin, P. 2014. Kedatuan Sriwijaya. Komunitas Bambu.

Falk, L. 1991. Historical Archaeology in Global Perspective. Smithsonian Institution Press.

Farida, I., Rochmiatun, E., \& Kalsum, N. U. 2019. Peran Sungai Musi dalam Perkembangan

Peradaban Islam di Palembang: Dari Masa Kesultanan Sampai Hindia-Belanda. Jurnal Sejarah Peradaban Islam, 3(1), 50-57.

Fauzi, M. R. 2016. Beberapa Hasil Awal Penelitian Arkeologi Di Kawasan Kars Bukit Bulan, Sarolangun. Siddhayatra, 21(1), 1-12.

Fauzi, M. R., Prasetyo, S. E., Andhifani, W. R., Hendrata, A. O., \& Intan, F. S. 2015. Laporan Penelitian Arkeologi: Survei Arkeologis Potensi Gua di Provinsi Jambi Tahap II.

Funari, P. P. A., Jones, S., \& Hall, M. 1999. Introduction: Archaeology in History. In Historical Archaeology: Back from the Edge (hal. 1-20). Routledge Taylor \& Francis Group.

Hidayat, R. 2012. Membangkitkan Batang Terendam: Sejarah Asal Usul, Kebudayaan dan Perjuangan Hak SAD Batin 9. Yayasan Setara Jambi.

Kozok, U. 2015. 14th Century Malay Code Of Laws: The Natisarasamuccaya. Institute Of Southeas Asian Studies.

Kristina, A., \& Azmi, U. 2019. Gereja Katholik St. Theresia Kota Jambi 1935-2011. Jurnal Ilmiah Istoria, 3(1), 47-62.

Lindayanti. 2014. Menyibak Sejarah Tanah Pilih Pusako Betuah. Badan Perpustakaan, Arsip dan Dokumentasi Kota Jambi.

Makmun, S. 2018. Peran Pemerintah Desa Lidung dalam Melestarikan Kesenian Islam Baghami (Studi Kasus di Desa Lidung, Kecamatan Sarolangun, Kabupaten Sarolangun, Provinsi Jambi). UIN Sultan Thaha Saifuddin.

Manguin, P. 2009. Southeast Sumatra in Protohistoric and Srivijaya Times: UpstreamDownstream Relations and the Settlement of the Peneplain. In D. Bonatz, J. Miksic, J. D. Neidel, \& M. L. Tjoa-Bonatz (Ed.), From Distant Tales: Archeology and Ethnohistory in the Highlands of Sumatra (hal. 434-484). Cambridge Scholars Publishing.

Marsden, W. 2013. Sejarah Sumatra. Komunitas Bambu.

Melisah. 2016. Laporan Registrasi Kepurbakalaan Kabupaten Sarolangun Provinsi Jambi.

Miftahurrahmat. 2018. Sejarah KH. Shirojuddin H. Muhammad Terhadap Pendidikan Islam di Pondok Pesantren Al-Jauharein Kelurahan Tanjung Johor Kecamatan 
Pelayangan, Seberang Kota Jambi. UNI Sultan Thaha Saifuddin.

Munandar, A. A. 1999. Berbagai Bentuk Ragam Hias pada Bangunan Hindu-Buda dan Awal Masuknya Islam di Jawa. Wacana, 1(1), 49-69.

Naim, M. 1982. Merantau Pola Migrasi Suku Minangkabau. Gadjah Mada University Press.

Orser Jr., C. E. 2010. Twenty-First-Century Historical Archeology. Journal of Archaeological Research, 18(2), 111-150.

Paynter, R. 2000. Historical and Anthropological Archaeology: Forging Alliances. Journal of Archaeological Research, 8(1), 1-37.

Rosyid, M. 2019. Menara Masjid Al-Aqsha Kudus: Antara Situs Hindu atau Islam. PURBAWIDYA: Jurnal Penelitian dan Pengembangan Arkeologi, 8(1), 15-27.

Saudagar, F. 1990. Penafsiran Situs Solok Sipin Sebagai Tempat Pemujaan Agama Buddha.

Scholten, E. L. 2008. Kesultanan Sumatera dan Negara Kolonial: Hubungan Jambi-Batavia 1830-1907 dan Bangkitnya Negara Kolonialisme Belanda. KITLV.

Sedyawati, E., Santiko, H., Djafar, H., Maulana, R., Ramelan, W. D. S., Wurjantoro, E., \& Utomo, B. B. 2014. Candi Indonesia II: Seri Sumatera, Bali, Kalimantan, Sumbawa. Direktorat Pelestarian Cagar Budaya dan Permuseuman, Direktorat Jenderal Kebudayaan, Kementerian Pendidikan dan Kebudayaan.

Serrato-Combe, A. 2003. The Aztec Templo Mayor-A Visualization. Journal of Architectural Computing, 3(1), 313-332.

Sujiyati, M., \& Ali, N. H. 2015. Pembangunan Kota Palembang dengan Konsep Tata Ruang Kota Hijau pada Masa Hindua-Belanda. Tamaddun, XV(1), 1-33.

Sukandar, I. 2014. Selayang Pandang Kota Jambi: Perkembangan Masyarakat dan Kebudayaannya.

Suratminto, L. 2008. Makna Sosio-Historis Batu Nisan VOC di Batavia. Wedatama Widya Sastra.

Syuhada, S., Supian, \& Seprina, R. 2017. Sejarah Kota Modern Masa Kolonial Belanda: Studi Kasus Kota Tua di Muaro Tembesi Batang Hari. Jurnal Titian, 1(1), 172-190.

Tideman, J. 1938. Djambi, Bewerkt door J. Tideman, Met Medewerkin. Bruk de Bussy.

Utomo, B. B. 1994. Swarnnadwipa Abad XIII-XIV Masehi Penggunaan Atas Sumber Emas di Hulu Batanghari (Sumatra Barat). Berkala Arkeologi. https://doi.org/10.30883/jba.v14i2.728

Utomo, B. B. 2016. Pengaruh Kebudayaan India dalam Bentuk Arca di Sumatra. Yayasan Pustaka Obor.

Yusuf, A. M. 2008. Presiden RI ke II Jenderal Besar HM Soeharto dalam Berita, Buku XI. 
Antara Pustaka Utama.

Zed, M. 2009. Kota Padang Tempoe Doeloe Zaman Kolonial. Pusat Kajian Sosial Budaya dan Ekonomi, Fakultas Ilmu-ilmu Sosial.

Zentgraaf, H. C., \& Goudoever, W. A. 1947. Sumatraantjes. Uitg. W. van Hoeve. 